Article

\title{
Strategies of Building a Stronger Sense of Community for Sustainable Neighborhoods: Comparing Neighborhood Accessibility with Community Empowerment Programs
}

\author{
Te-I Albert Tsai \\ Department of Landscape Architecture, Chinese Culture University, 55, Hwa-Kang Road, \\ Yang-Ming-Shan, Taipei City 11114, Taiwan; E-Mail: teiatsai@gmail.com or \\ cdy3@faculty.pccu.edu.tw; Tel.: +886-9-5325-7755; Fax: +886-2-2838-3205
}

Received: 7 February 2014; in revised form: 28 April 2014 / Accepted: 29 April 2014 /

Published: 13 May 2014

\begin{abstract}
New Urbanist development in the U.S. aims at enhancing a sense of community and seeks to return to the design of early transitional neighborhoods which have pedestrian-oriented environments with retail shops and services within walking distances of housing. Meanwhile, 6000 of Taiwan's community associations have been running community empowerment programs supported by the Council for Cultural Affairs that have helped many neighborhoods to rebuild so-called community cohesion. This research attempts to evaluate whether neighborhoods with facilities near housing and shorter travel distances within a neighborhood would promote stronger social interactions and form a better community attachment than neighborhoods that have various opportunities for residents to participate in either formal or informal social gatherings. After interviewing and surveying residents from 19 neighborhoods in Taipei's Beitou District, and correlating the psychological sense of community with inner neighborhood's daily travel distances and numbers of participatory activities held by community organizations under empowerment programs together with frequencies of regular individual visits and casual meetings, statistical evidence yielded that placing public facilities near residential locations is more effective than providing various programs for elevating a sense of community.
\end{abstract}

Keywords: sense of community; new urbanism; community empowerment; pedestrian friendly environment; neighborhood accessibility 


\section{Introduction}

Through providing a pedestrian-friendly environment for increasing residents' face-to-face opportunities and casual social interactions between neighbors, developers and planners in the U.S. have adopted New Urbanist (NU) development strategies seeking to return to the design of the early transitional neighborhoods to enhance the sense of community (SOC) [1-5]. Many studies have supported the theory that providing pedestrian environment will enhance an SOC, but very few have looked into the influence of neighborhood accessibility.

The Council for Cultural Affairs in Taiwan have been initiating community empowerment programs since 1994. Many community associations located in either urbanized or rural areas were founded that run programs to reach a community consensus and promote their self-governance ability for maintaining sustainable community growth during the participation process [6]. Hosting a variety of community activities to encourage residents' interactions has become the main strategy used by many community associations, and most discussions in Taiwan have overemphasized participation experience sharing and applications of different strategies [7]. None of them has ever explored the effectiveness of adopting the empowerment strategies on SOC quantitatively.

Two notions are examined in the study. One is "neighborhoods with shorter inner neighborhood travel distances, resulting from having grocery stores and community services within certain distances in a neighborhood, are likely to encourage walking and cycling and to provide more opportunities for social interactions, thereby an SOC is strengthened". The other is "neighborhoods having more residents participating in community events are likely to facilitate better community attachment due to having chances of interacting with others". This study attempts to compare the effectiveness of two different approaches, through correlating psychological sense of community (PSOC) with factors of inner neighborhood travels and frequencies of group gatherings based on 19 neighborhoods within the Beitou District in Taipei, Taiwan.

\section{Past Literature}

"Community" in Merriam-Webster dictionary is defined as "the people with common interests living in a particular area", and "neighborhood" is clarified as "the people living near one another". Tseng [6] defined neighborhood as a geographically bounded area based on political boundary. It is within a larger city, town, or suburb. The term of "community" is often linked to social and face-to-face interactions among residents and it is therefore more associated with the power of attachment. On the other hand, according to Taipei's Self-Governance Administration Regulations on Defining District and Neighborhood Boundary, neighborhood is defined by the criteria of population density and numbers of household within an area. To facilitate the following discussion, "neighborhood" is based on Taipei City's political boundary and "community" is about residents living together with a common character.

When the concept of SOC is used by social psychologists, it is often referred to PSOC. Sarason [8] defined PSOC as the perception of similarity to others, and it can be an acknowledged interdependence with others, or a willingness to maintain this interdependence by giving to or doing for others, or the feeling that one is part of a larger dependable and stable structure. Similarly, McMillan and Chavis [9] 
theorized SOC as "a feeling that members who matter to one another within the group and of belonging and a shared faith that members' needs will be met through their commitment to be together." Here, SOC is also a component of social capital [10], which Putnam [11] defined as links of people having a sense of common identity, of people stretching beyond a shared sense of identity, and of people or groups further up or lower down the social ladder. Whichever term is used, based on qualitative discussion, an SOC is mainly about the bonding experience of community members in a spatial formation based on either a community or a neighborhood.

Kim and Kaplan [5] researched two residential communities in Gaithersburg, Maryland, and classified four domains under SOC, according to their preliminary interviews of 20 residents living in Kentlands and 10 in Orchard Village, and questionnaire surveys of households located in both communities. The four domains defined by them are: community attachment, social interaction, community identity and pedestrianism. "Pedestrianism" and "social interaction" are activity-oriented concepts, and "community identity" and "community attachment" are related to meaning aspects of communities. Moreover, neighborhood spatial settings and the community identity seem to be the intermediate factors of influencing pedestrianism on the degree of community cohesion [1].

To understand the underlying relationship of SOC with neighborhood spatial configuration and empowerment programs, literatures of measuring SOC quantitatively based on 11 Likert-Scale questions together with pedestrianism and accessibility are discussed below.

\subsection{Community Attachment and Social Interaction}

Community attachment is about a resident's feeling or emotion of bonding to his or her community and the sense of connection to the community. It is affected by the ownership of controlling over their homes/community and long-term residency. Social interaction is about residents talking, smiling, negotiating, fighting, or debating to/with one another. It can be classified into formal (such as attending planned events) and informal (such as meeting casually) types, and both of them include neighboring, casual encounters, activity participation and social support [5]. Nasar and Julian [2] also included these components for measuring PSOC in their research by adopting the 11 Likert-scale questions. Generally, many past studies assume that residents of longer residency is likely to have more opportunities involving in longer social interaction, thereby a stronger SOC is formed. However, Lund [4] and Rosenblatt and others [12] found a weak linkage.

\subsection{Community Identity and Sense of Community}

Community identity is about either the cumulative effects of perception based on residents' races, income classes, and genders, or the physical characters of the community setting and environments. Relph [13] classified seven types of place identity (existential insideness, empathetic insideness, behavioral insideness, incidental outsideness, objective outsider, mass identity of place, and existential outsideness). Most of these identities could be identified by residents or visitors easily through comparing the place differences between natural and man-made settings or cultural conditions. However, "mass identity" could be manipulated by mass media and "existential outsideness" may exist incidentally without relating to the surroundings or people. 
Gospodini [14] examined relationship of place identity of European cities between built heritage and the innovative design of space, through interviewing and questionnaire surveying inhabitants and visitors. He found that identities based on built heritages tended to get weaker while comparing it with innovative design of structures. Moreover, many researchers believe that community identity and SOC are positively correlated with the self-organizing communities [2,8,15-17].

Punter [18] and Montgomery [19] defined the sense of place as the center area where settings, activities, and meanings intersect together. Gotham [20] believed that resident's attachment to a place or a community is a requisite power for neighborhood collective action and mobilization. To share the experience of community empowerment processing, Tseng [6] identified several unique community features and concluded that a community with a distinctive identity is likely to facilitate its SOC, after his examination of seven Taiwan's communities. However, $\mathrm{Wu}$ [7] suspected that community identity is unassociated with the degree of SOC, based on his study of communities in Tainan, Taiwan. Lee [21] found that much so called community identity in Taiwan has become a commodity for attracting tourists and is irrelevant to an SOC, after his comparison of Taiwan's community empowerment progress under globalization by reviewing literature on community empowerment progress. There is still inconclusive debate on the relationship between identity and SOC.

\subsection{Pedestrianism and Neighborhood Accessibility}

Pedestrianism reflects the extent of a neighborhood which is designed for walking, for fostering street-side activities, and for helping people find their way [16]. By encouraging residents interacting with one another while they walking or cycling, researchers and planners believe that providing pedestrian-friendly environment associated with walkability was strongly correlated with SOC [1,4,5,22,23]. Moreover, to determine the factors associated with accessibility at the neighborhood level and to understand tools of measuring neighborhood accessibility, Handy and Clifton [24] reviewed the literature on accessibility measures and identified factors in relating with travel behavior and planning practice. They find that "location and distance" are the two most important elements for measuring neighborhood walkability and accessibility, since locations of facilities such as community centers, neighborhood parks, and elementary schools could affect inner neighborhood travel behavior, resulting in an increase of social interactions. Bromley et al. [25] believed that the promotion of city center living could lead to neighborhood regeneration and form better community cohesiveness, through locating facilities near residential areas. Tsai [26] examined 17 Beitou neighborhoods in Taipei, Taiwan, based on self-sustained and self-governance concepts, and found that a stronger degree of SOC is contributed to by shorter inner neighborhood daily travel distance.

\subsection{Measuring Sense of Community Based on 11 Questions in Likert Scale}

Partially similar to the concept of Chi-Square of Goodness-of-Fit Test (comparison between observed and expected values), Glynn's questions of measuring PSOC included 13 open-ended questions, 60 forced-choice items about actual community setting, and 60 identical forced-choice inquiries of ideal community [27]. Generally, these questions could be classified into six dimensions: objective evaluation of community structure, supportive relationships in the community, similarity and relationship patterns of community residents, individual involvement in the community, quality of 
community environment, and the community security [4]. Filipovič Hrast and Dolničar [28] grouped their 15 questions of measuring SOC into 3 categories, which are contact with neighbors, social control, and attachment.

For considerations of easy application and selection of an appropriate scale, Nasar and Julian [2] employed discriminatory power of 11 questions for measuring PSOC, after their simplifying Glynn's psychometric evaluation [27]. Both positive and negative descriptions of items were used by them for checking the reliability and validity between questions. They found that married couples with children, residents living in the courtyard apartment complex and in a mixed-use neighborhood tended to have a stronger SOC. Lund [4] used the 11-item of questions to examine two hypotheses: residents living in traditional neighborhoods will have a higher SOC than in modern suburban neighborhoods, and the qualities of neighborhoods' pedestrian environments will significantly contribute to residents' SOC. After her controlling various demographic variables and conducting surveys in one pedestrian-oriented neighborhood and one automobile-oriented neighborhood in Portland, Oregon, she found that SOC will be greater in the traditional neighborhood and pedestrian environment factors will significantly influence an SOC.

\subsection{Review of Taiwan's Community Empowerment Program Influencing on Sense of Community}

To help communities capable of maintaining community sustainable growth, the theory of "Grass Roots Democracy" emphasizes on the importance of local self-government by employing a bottom-up citizen participating approach for gathering community and for forming stronger attachment $[29,30]$. Accordingly in Taiwan, during the period of 1960, the concept of community empowerment was initiated by Taiwan's government to respond to the growing grass-root democracy movement, and many so called "Culture and History Workshops" were established for unveiling the forgotten cultural stories behind communities with assistance of government's financial supports. These workshops later became the foundation of creating community associations with missions of implementing three tasks: improving community's public facilities, providing social welfare programs such as the provision of childcare and elderly care, and enhancing community interaction such as regularly hosting cooking classes for housewives to get to know each other.

According to the 2010 Ministry of the Interior statistics, there were approximately 6000 community associations located in 7810 neighborhoods, and about $40 \%$ of them were in metropolitan areas. Chang [31] evaluated community empowerment programs in Taiwan's rural agricultural areas, through conducting 189 interviews from 50 different villages. He found that rural communities with better ability of self-governance are usually supported by local economic development and well-planned organizations hosting a variety of empowerment programs. Tseng [6] found that people living in those urban edge neighborhoods characterized with lower living cost, diverse background, and blue-collar workers tended to have a weaker SOC, according to his study on Taiwan's 72 communities.

Due to geographic configuration difference and resource limitation, Taiwan's empowerment programs supported by community associations generally are grouped into three types. Community associations in the urbanized area frequently address issues of quality of life and provide programs such as streetscape cleaning, community gardening, opposing NIMBY facilities, and hosting special or educational events for gathering residents. Community associations in suburban towns usually promote 
cultural and historical preservation, and regularly arrange programs such as religious ceremonies and festival parties. Surrounded within the ecological setting, community associations in rural agricultural area or suburb often emphasize on environmental protection and promote ecological tourism. Here, whether empowerment programs are able to promote a stronger SOC, a further quantitative examination is needed before reaching any conclusion $[21,26]$.

\section{Method}

To unveil the relationships between PSOC, neighborhood activities and spatial configurations, neighborhoods in Taipei's Beitou District were selected as the study area. Both qualitative and quantitative methods are employed for analyses. Qualitative methods include household questionnaire surveys, and interviews with heads of households and with leaders or members of community associations. Then, quantitative analysis such as a forward stepwise regression is employed to examine the statistically importance between PSOC with the frequency of residences participating in community activities and average distances of inner neighborhood travel.

Figure 1 is the analytical framework for determining causalities between PSOC and variables of setting, activities, meanings (community identities and stories), backgrounds of residents and characteristics of households. The model (1) is:

Figure 1. Analytical Framework.

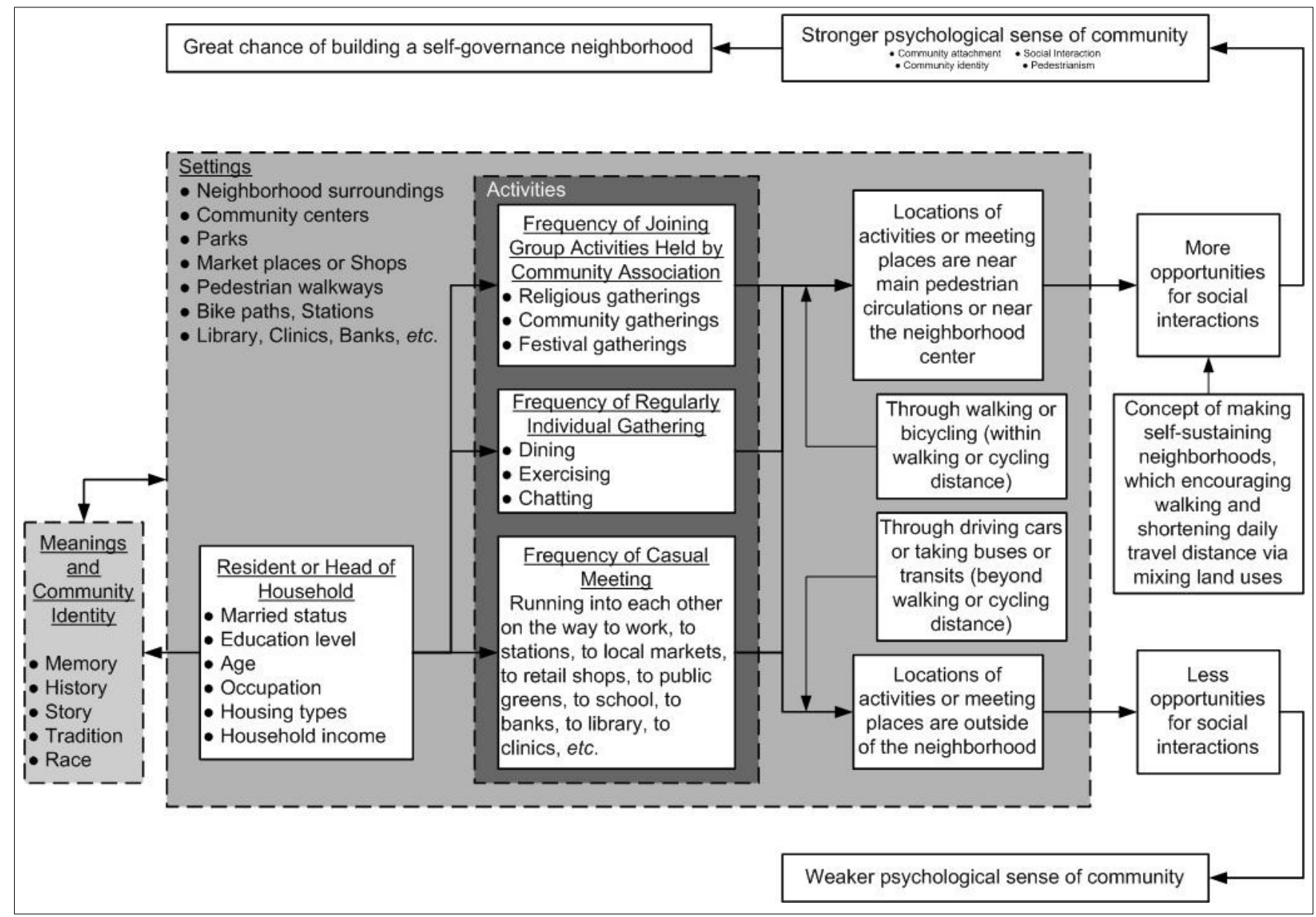




$$
\text { Degree of PSOC }=f(\text { Bckgrnd }+ \text { ActvtyDstnc }+ \text { FrquncyMtng })
$$

where:

- "Degree of PSOC" is the degree of psychological sense of community based on neighborhood unit;

- "Bckgrnd" is the backgrounds of residents and their household conditions together with neighborhood identity (unique character or identity of their community) at neighborhood scale;

- "ActvtyDstnc" is the settings and physical spatial configurations of types of activities found at several locations within the neighborhoods; and

- "FrquncyMtng" is the frequencies of residents participating in social activity gatherings.

\subsection{Independent Variables}

Variables of background include resident's married status, number of children per household, annual household income, education level, age, occupation, and housing type. For meanings, the variable includes types of neighborhood identity, which refer to the share of memories, histories, stories, cultural traditions, and place attachment within the neighborhood. Interviews were conducted to understand the identity and the result is shown in Table 1.

Variables of settings refer to various neighborhood daily activities located, and include the average of travel distances based on different trip purposes from homes to a variety of public places and services such as parks, market places and transit stations, on a neighborhood scale.

The survey questionnaire of this research asked every interviewee (head of household) to provide actual average daily travel time without counting traffic congestion and specify mode of transport chosen for different trip purposes such as commuting to works, shopping, exercising, doing recreation, taking children to school, going to the library, travelling to banks or the post office, going to clinics, and attending community activities. If the locations of activities are happened within walking or cycling distance, residents are assumed to have more opportunities to meet with each other and an SOC is likely to be stronger. In contrast, if the locations of activities are beyond walking distance and residents have to drive cars or take transits to the destinations, fewer opportunities of social interactions are likely to weaken an SOC. If there were more than one walking persons in the household and each of them has different travel pattern, the resident was asked to provide an average travel time in general. Later, average travel time is converted into the travel distance.

Variables of social activity gatherings include the frequency of attending group activities arranged by community associations per household weekly (formal meetings), the frequency of running into with neighbors per household weekly (informal casual meetings), and the frequency of individual gathering per household weekly (informal meetings), at neighborhood scale. Here, formal group activities include religious gatherings, community gathering, and festival gatherings. Regular individual gatherings mainly imply that residents participating informal meetings routinely at locations such as restaurants for dining, parks or community recreational centers. Casual meetings are about neighbors running into each other on the way to work, local markets, public greens, schools, and even front doors. 
Table 1. Characters of 19 selected neighborhoods.

\begin{tabular}{|c|c|c|c|c|c|c|c|c|}
\hline \multirow{2}{*}{ Characters } & \multirow{2}{*}{$\begin{array}{c}\text { Number of } \\
\text { questionnaire } \\
\text { survey } \\
\text { obtained }\end{array}$} & \multirow[b]{2}{*}{$\begin{array}{l}\text { Population } \\
\text { in } 2009\end{array}$} & \multirow{2}{*}{$\begin{array}{c}\text { Number of } \\
\text { households } \\
\text { in } 2009\end{array}$} & \multirow{2}{*}{$\begin{array}{l}\text { Number of } \\
\text { members } \\
\text { joining } \\
\text { community } \\
\text { association } \\
\text { in } 2009 \\
\end{array}$} & \multicolumn{3}{|c|}{$\begin{array}{c}\text { Ratio of housing type in } \\
\text { the neighborhood }\end{array}$} & \multirow{2}{*}{$\begin{array}{c}\text { Neighborhood identity } \\
\text { (Information obtained } \\
\text { through interviewing } \\
\text { residents) }\end{array}$} \\
\hline & & & & & $\begin{array}{c}\text { Under } \\
\mathbf{3} \\
\text { stories }\end{array}$ & $\begin{array}{c}3-5 \\
\text { stories }\end{array}$ & $\begin{array}{c}\text { Above } \\
5 \\
\text { stories }\end{array}$ & \\
\hline Suburban Area & 65 & 5394 & 1968 & 223 & $96 \%$ & $4 \%$ & $\mathbf{0 \%}$ & Natural feature mainly \\
\hline Hu-Tian & 32 & 977 & 383 & 80 & $98 \%$ & $2 \%$ & $0 \%$ & Lily of Nile plantation \\
\hline Hu-Shan & 12 & 1936 & 748 & 53 & $95 \%$ & $5 \%$ & $0 \%$ & Hot Spring \\
\hline Quan-Yuan & 21 & 2481 & 837 & 90 & $96 \%$ & $4 \%$ & $0 \%$ & Plantation \\
\hline Urbanized Area & 331 & 94446 & 39353 & 1670 & $39 \%$ & $50 \%$ & $11 \%$ & Man-made feature \\
\hline Xiu-Shan & 19 & 3435 & 1164 & 210 & $85 \%$ & $14 \%$ & $1 \%$ & Townhouses on slope \\
\hline Yong-Xin & 16 & 7799 & 3080 & 50 & $64 \%$ & $27 \%$ & $9 \%$ & Luxury high-rises \\
\hline Zhong-He & 12 & 4942 & 1850 & 80 & $45 \%$ & $52 \%$ & $3 \%$ & Urban edge community \\
\hline Qi-Yan & 14 & 9872 & 3341 & 320 & $67 \%$ & $29 \%$ & $4 \%$ & $\begin{array}{l}\text { Wetland, Food co-op } \\
\text { store }\end{array}$ \\
\hline Guan-Du & 19 & 11020 & 3649 & 100 & $20 \%$ & $79 \%$ & $1 \%$ & $\begin{array}{c}\text { Temple, Mangrove } \\
\text { wetland }\end{array}$ \\
\hline Zhen-Hua & 19 & 7966 & 2745 & 80 & $23 \%$ & $66 \%$ & $11 \%$ & $\begin{array}{c}\text { Next to regional } \\
\text { hospitals }\end{array}$ \\
\hline Li-Xian & 27 & 5719 & 1914 & 100 & $11 \%$ & $84 \%$ & $5 \%$ & No unique feature \\
\hline Li-Nong & 38 & 9294 & 3102 & 68 & $25 \%$ & $72 \%$ & $3 \%$ & No unique feature \\
\hline Rong-Guang & 18 & 7828 & 2618 & 156 & $35 \%$ & $62 \%$ & $3 \%$ & Local night market \\
\hline Fu-Xing & 19 & 7483 & 2524 & 100 & $24 \%$ & $71 \%$ & $5 \%$ & No unique feature \\
\hline Da-Tong & 23 & 6480 & 2256 & 72 & $54 \%$ & $33 \%$ & $13 \%$ & Night market \\
\hline Rong-Hua & 16 & 7935 & 2871 & 70 & $31 \%$ & $36 \%$ & $33 \%$ & Next to regional hospitals \\
\hline Ji-Qing & 39 & 5594 & 1853 & 90 & $19 \%$ & $75 \%$ & $6 \%$ & No unique feature \\
\hline Zhong-Yang & 16 & 8674 & 3104 & 78 & $34 \%$ & $65 \%$ & $1 \%$ & No unique feature \\
\hline Dong-Hua & 16 & 4894 & 1612 & 60 & $69 \%$ & $26 \%$ & $5 \%$ & Irrigation channel \\
\hline Wen-Hua & 20 & 4658 & 1670 & 36 & $16 \%$ & $10 \%$ & $74 \%$ & Army community \\
\hline
\end{tabular}

\subsection{Dependent Variable}

The dependent variable (PSOC) is defined by 11 questions in a five-point Likert scale of ordinal number ranging from strongly disagree (1 point) to strongly agree ( 5 points), which is similar to Lund's measurement. To aggregate a degree of PSOC at neighborhood level and minimize the double-barreled problem, three phases of calculation were proceeded by comparing the score of individual's PSOC with the average PSOC score of the selected samples, at individual, neighborhood per se, and the selected neighborhood levels. Based on the Method of Reciprocal Averages concept [32], the final score of a neighborhood's PSOC is determined by subtracting the average PSOC's weighted score of 19 selected neighborhoods from the score of a neighborhood's PSOC. Here, a larger number of PSOC score (positive value) is referred to a stronger degree of SOC relatively.

Tables 2 and 3 show a summary of the variables categorized by urbanized and suburban neighborhoods in form of mean, median and standard deviations (S.D.). Here, based on the criterion of 
average travel time from neighborhood centers to Taipei's Main Train Station, urbanized neighborhoods are defined as their residents travel less than 50 minutes by transit, and residents of suburban neighborhoods need more than 1 hour by automobile without rail transit service. Please note that urbanized and suburban types of neighborhoods are only used for describing general household's characters, travel behavior, spatial configurations and frequencies of interviewee attendance in three types of activities. The remaining analyses are discussed based on neighborhood level.

Table 2. List of independent variables and statistics.

\begin{tabular}{|c|c|c|c|c|c|c|}
\hline \multirow[b]{2}{*}{ Variables } & \multicolumn{3}{|c|}{ Suburban } & \multicolumn{3}{|c|}{ Urbanized } \\
\hline & Mean & Median & S.D. & Mean & Median & S.D. \\
\hline $\begin{array}{l}\text { Median Degree of PSOC of the selected } \\
\text { neighborhoods }\end{array}$ & -0.0294 & -0.0278 & 0.0510 & -0.0114 & -0.0108 & 0.0976 \\
\hline $\begin{array}{l}\text { Persons Per Household of the selected } \\
\text { neighborhoods in year } 2009\end{array}$ & 2.71 & 2.60 & 0.19 & 2.89 & 2.96 & 0.19 \\
\hline $\begin{array}{l}\text { Population Density (Persons } / \mathrm{Km}^{2} \text { ) of the selected } \\
\text { neighborhoods in year } 2009\end{array}$ & 7328.2 & 492.37 & 9974.3 & $22,405.15$ & 15,8778 & $19,697.9$ \\
\hline $\begin{array}{l}\text { Ratio of Housing Type under } 3 \text { Stories of the } \\
\text { selected neighborhoods }\end{array}$ & 0.9633 & 0.9600 & 0.0125 & 0.4047 & 0.3100 & 0.2453 \\
\hline $\begin{array}{l}\text { Ratio of Housing Type between } 3-5 \text { Stories of the } \\
\text { selected neighborhoods }\end{array}$ & 0.0367 & 0.0400 & 0.0125 & 0.4984 & 0.5962 & 0.2546 \\
\hline $\begin{array}{l}\text { Ratio of Housing Type higher than } 5 \text { Stories of } \\
\text { the selected neighborhoods }\end{array}$ & 0.0000 & 0.0000 & 0.0000 & 0.0922 & 0.0300 & 0.1800 \\
\hline $\begin{array}{l}\text { Average Distance from Neighborhood Center to } \\
\text { Mass Transit Station (Meter) }\end{array}$ & 2545.0 & 2400.0 & 1948.0 & 608.24 & 465.00 & 510.92 \\
\hline $\begin{array}{l}\text { Mean Duration of Living of the selected } \\
\text { neighborhoods }\end{array}$ & 14.55 & 13.56 & 2.79 & 15.75 & 15.59 & 2.39 \\
\hline $\begin{array}{l}\text { Ratio of Households having married couples with } \\
\text { children of the selected neighborhoods }\end{array}$ & 0.4407 & 0.4333 & 0.0909 & 0.3461 & 0.3125 & 0.1517 \\
\hline $\begin{array}{l}\text { Mean Age of the selected Neighborhoods (based } \\
\text { on interviewees) }\end{array}$ & 43.65 & 43.33 & 3.57 & 49.81 & 48.75 & 7.40 \\
\hline $\begin{array}{l}\text { Ratio of Education Level under College of the } \\
\text { selected neighborhoods }\end{array}$ & 0.6593 & 0.6667 & 0.1725 & 0.5574 & 0.5000 & 0.1759 \\
\hline $\begin{array}{l}\text { Median of Daily Travel Distance of the selected } \\
\text { neighborhoods }(\mathrm{Km})\end{array}$ & 31.38 & 37.69 & 11.57 & 19.93 & 12.98 & 22.72 \\
\hline $\begin{array}{l}\text { Median Daily Travel Distance without Commuting } \\
\text { Trips of the selected neighborhoods (Km) }\end{array}$ & 3.89 & 4.37 & 1.28 & 2.82 & 2.10 & 2.58 \\
\hline $\begin{array}{l}\text { Frequency of Casual Meeting per Household of } \\
\text { the selected neighborhoods weekly }\end{array}$ & 0.6520 & 0.7778 & 0.2184 & 0.9235 & 0.8400 & 0.4351 \\
\hline $\begin{array}{l}\text { Frequency of Attending Individual Gathering } \\
\text { Regularly of the selected neighborhoods weekly } \\
\text { per household }\end{array}$ & 0.1750 & 0.1111 & 0.1749 & 0.2820 & 0.2632 & 0.2436 \\
\hline $\begin{array}{l}\text { Frequency of Meeting Neighbors While } \\
\text { Attending Group Activities of the selected } \\
\text { neighborhoods weekly per household }\end{array}$ & 0.5792 & 0.5000 & 0.1530 & 0.4765 & 0.4444 & 0.2725 \\
\hline $\begin{array}{l}\text { Median Annual Household Income of the selected } \\
\text { neighborhoods (based on interviewees) }\end{array}$ & 576,666 & 185,000 & 553,900 & 724,981 & 772,500 & 514,334 \\
\hline $\begin{array}{l}\text { Median Distance from Home to Leisure Places of } \\
\text { the selected neighborhoods }\end{array}$ & 1.88 & 1.25 & 1.03 & 1.35 & 1.00 & 0.75 \\
\hline
\end{tabular}


Table 3. List of dependent variables and statistics.

\begin{tabular}{l|ccc|ccc}
\hline \multicolumn{1}{c}{ Neighborhoods } & \multicolumn{3}{|c|}{ Suburban } & \multicolumn{3}{c}{ Urbanized } \\
\cline { 2 - 7 } Variables & Mean & Median & S.D. & Mean & Median & S.D. \\
\hline $\begin{array}{l}\text { 1. If I feel like talking, I can generally find } \\
\text { someone in this neighborhood to talk to } \\
\text { right away. }\end{array}$ & 3.3595 & 3.5556 & 0.3761 & 3.7881 & 3.8235 & 0.3807 \\
\hline $\begin{array}{l}\text { 2. My friends in this neighborhood are part } \\
\text { of my daily living. }\end{array}$ & 3.3640 & 3.3333 & 0.3105 & 3.5600 & 3.5600 & 0.4331 \\
\hline $\begin{array}{l}\text { 3. If someone does something good for this } \\
\text { neighborhood, that makes me feel good. }\end{array}$ & 4.2446 & 4.3448 & $\mathbf{0 . 3 0 3 2}$ & 4.4028 & 4.4375 & $\mathbf{0 . 1 8 5 1}$ \\
\hline $\begin{array}{l}\text { 4. If I had an emergency, even people I do } \\
\text { not know in this neighborhood would be } \\
\text { willing to help. }\end{array}$ & 3.8148 & 3.7778 & $\mathbf{0 . 1 3 8 6}$ & 3.7897 & 3.7778 & $\mathbf{0 . 2 5 7 6}$ \\
\hline $\begin{array}{l}\text { 5. The police in this neighborhood are } \\
\text { generally friendly. }\end{array}$ & 3.8563 & 4.0690 & 0.4995 & 4.0214 & 4.0625 & 0.3408 \\
\hline $\begin{array}{l}\text { 6. I am quite similar to most people who } \\
\text { live here. }\end{array}$ & 3.0958 & 3.6207 & $\mathbf{0 . 7 7 5 1}$ & 3.5166 & 3.5625 & $\mathbf{0 . 3 8 6 7}$ \\
\hline $\begin{array}{l}\text { 7. I have no friends in this neighborhood } \\
\text { on whom I can depend. }\end{array}$ & 3.1775 & 3.3103 & 0.3748 & 3.2368 & 3.2222 & 0.3052 \\
\hline $\begin{array}{l}\text { 8. I do not care whether this neighborhood } \\
\text { does well. }\end{array}$ & 2.1296 & 2.0000 & 0.2658 & 2.0632 & 2.0000 & 0.3013 \\
\hline $\begin{array}{l}\text { 9. If I am upset about something personal, } \\
\text { there is no one in this neighborhood to } \\
\text { whom I can turn. }\end{array}$ & 2.4111 & 2.2333 & 0.4272 & 2.4874 & 2.4118 & 0.3557 \\
\hline $\begin{array}{l}\text { 10. People here know they can get help } \\
\text { from others in the neighborhood if they } \\
\text { are in trouble. }\end{array}$ & 3.4370 & 3.4444 & 0.3539 & 3.6330 & 3.7105 & 0.2903 \\
\hline $\begin{array}{l}\text { 11. If there were a serious problem in this } \\
\text { neighborhood, the people here could get } \\
\text { together to solve it. }\end{array}$ & 3.5111 & 3.8667 & $\mathbf{0 . 5 9 9 6}$ & 3.7115 & 3.7647 & $\mathbf{0 . 3 0 9 3}$ \\
\hline
\end{tabular}

Generally, both tables show that urbanized neighborhoods have higher standard deviations than the suburban in categories of median degree of PSOC, ratio of housing types under five stories, ratio of households having married couples with children, mean ages, travel distances, and frequencies of informal activity gatherings. Moreover, the differences of the mean and median values shows that urbanized neighborhoods tend to have a stronger degree of SOC, denser population, higher ratio of building type of five stories taller, and more casual gathering opportunities. In contrast, residents of suburban neighborhoods travel longer distances daily. The deviations of most PSOC measurement items for suburban neighborhoods are more diverse than the urbanized neighborhoods. This implies that the suburban neighborhoods tend to have a weaker SOC.

\subsection{Data Collection}

The data collected for both explanatory and dependent variables were mainly from questionnaire survey. To co-respond to questionnaire survey completed in year 2009, statistical demographic data of 
population numbers, households, and neighborhood's area were extracted from the 2009 Taipei's Census, which was collected yearly and available online at Taipei's Household Registration Offices. To understand community identities and resident's daily activity patterns in their neighborhood, community associations were chosen as focus groups for interviewing.

Before proceeding resident's questionnaire survey, the research team conducted a series of interviews via setting up appointments with every community leader to understand neighborhood general condition (such as resident's daily living patterns, locations of public places, and activities and events held by community associations). After interviews, questionnaires including background of interviewee, average daily travel time from origins to destinations, mode choices and 11 questions of measuring PSOC, were distributed to the neighborhoods for household surveys.

Although there were 44 community associations in 42 neighborhoods in Taipei's Beitou district (as shown in Figure 2), only 20 associations accepted our interviews. Later, only 14 of 20 community associations were willing to join the follow-up questionnaire survey. However, while the research team was collecting the data of 14 associations, we were fortunate to meet residents from other neighborhoods, thereby enabling us to obtain additional data from 5 other neighborhoods. In total, 417 questionnaires were collected. 396 were effective and 19 neighborhoods were included in the final analysis. $98 \%$ of interviewees were members of community associations, and every neighborhood contained at least 10 survey samples. Table 1 lists the numbers of surveys collected from each neighborhood.

Figure 2. Location of Beitou's 42 neighborhoods in Taipei.

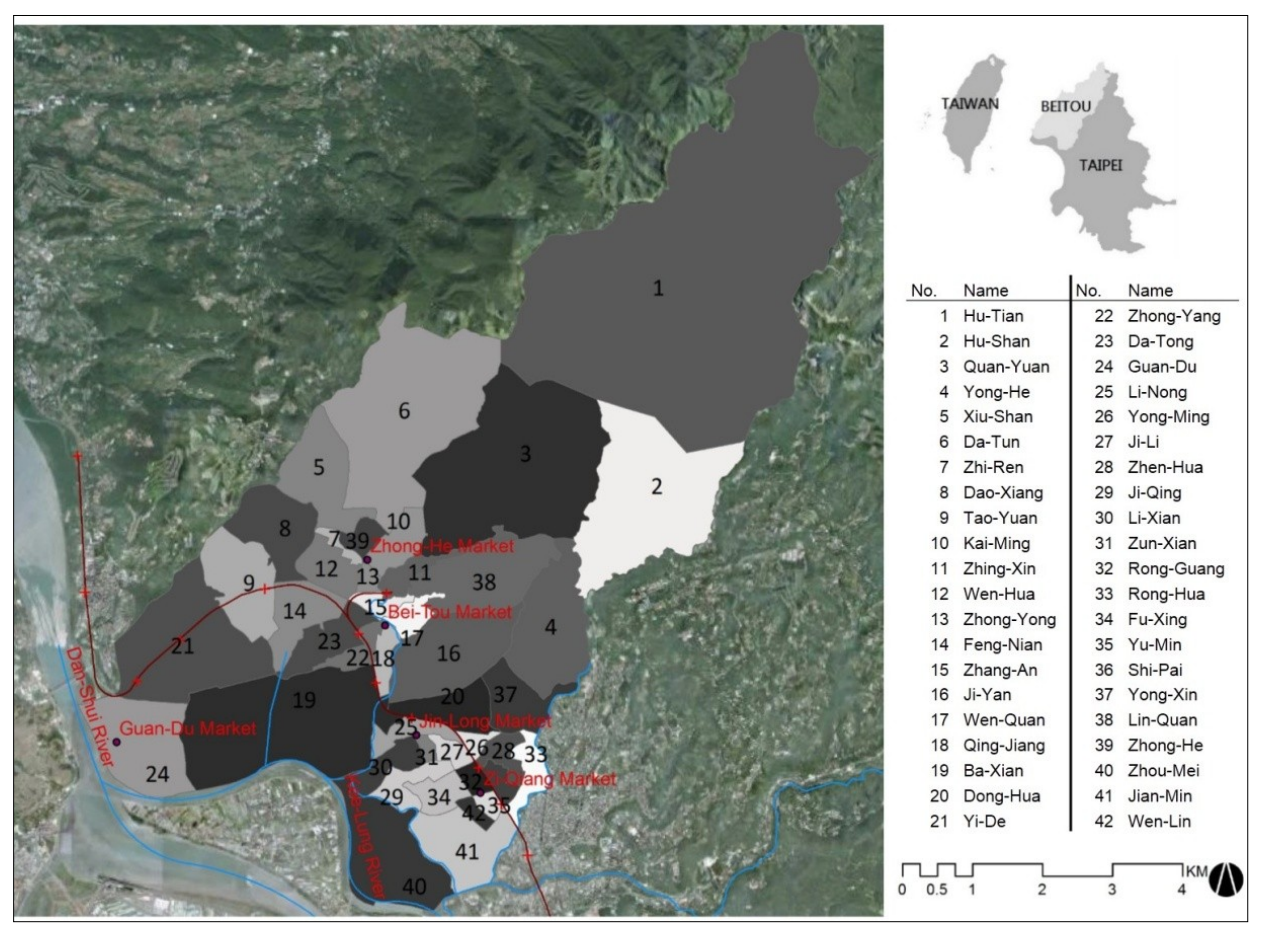

\section{Existing Neighborhood Identity and Situations of 19 Selected Neighborhoods}

Located at the suburb of northern Taipei City in an area of 56.82 square kilometers, Beitou district is surrounded by Yang-Ming Mountain and Da-Tun Mountain on its eastern and northern edges, together with Dan-shui River on its south and west. The population density was about 4400 persons 
per $\mathrm{km}^{2}$ in year 2009. There were 250,000 residents living in 42 neighborhoods and about 2.8 persons per household in average. Among the 42 neighborhoods, 3 are adjacent to the river. Three suburban neighborhoods featuring with volcano geography and hot springs are situated in the mountains. Thirteen neighborhoods are on the lower elevation of mountain slopes and 23 urbanized neighborhoods are served by the mass transit with stations near their neighborhood cores. Generally, neighborhood identities of 42 neighborhoods can be categorized into seven types, which are mountain slope community, agricultural plantations, historical temples, local markets, wetlands, hot spring, and ethnic groups.

There are five market places in Beitou's urbanized neighborhoods. Four markets are situated along mass transit line, and one is adjacent to Dan-Shui riverfront. Most residential houses standing within radii of 400 and 800 meters around the five market places are lower floors for commercial and public uses together with upper floors for residential usage. Few office buildings are located in the ring from the radius of 400 to 800 meters centered at market places. Ninety percent of businesses and services are situated near markets within a radius of 1200 meters. Moreover, Table 1 also shows the ratio of different housing types of urban form for the 19 selected neighborhoods.

Generally, Table 4 shows that 3 suburban neighborhoods have natural features as their identities and 16 urbanized neighborhoods (residential usage mixing with commercial and retail activities along with major arterials) are characterized by their man-made structures. Table 4 lists a detailed empowerment programs held by community association and places chosen for formal activity gathering. Clearly, suburban neighborhoods tend to choose private homes as gathering places and urbanized neighborhoods mainly select community offices as community interaction places.

Table 4. Empowerment programs held by 19 selected community associations.

\begin{tabular}{|c|c|c|c|}
\hline Characters & $\begin{array}{l}\text { Empowerment programs held by } \\
\text { community association } \\
\text { (Information obtained through } \\
\text { face-to-face interviewing } \\
\text { community associations) }\end{array}$ & $\begin{array}{l}\text { Most place chosen for } \\
\text { group gathering held by } \\
\text { community association }\end{array}$ & $\begin{array}{l}\text { Financial resource for } \\
\text { running community } \\
\text { association }\end{array}$ \\
\hline Suburban Area & \multicolumn{3}{|c|}{ Mainly private house } \\
\hline Hu-Tian & Ecotourism, Lily of Nile festival & Private house or Restaurant & $\begin{array}{l}\text { Membership fee, } \\
\text { Government funding }\end{array}$ \\
\hline Hu-Shan & $\begin{array}{l}\text { Local Chinese orchestra, Bakery class, } \\
\text { Religious ceremony }\end{array}$ & $\begin{array}{l}\text { Private house, } \\
\text { Community office }\end{array}$ & Membership fee \\
\hline Quan-Yuan & $\begin{array}{l}\text { Local Chinese orchestra, Religious } \\
\text { ceremony, Festival parties, Yoga class }\end{array}$ & Private house & Membership fee \\
\hline Urbanized Area & \multicolumn{3}{|c|}{ Mainly community office } \\
\hline Xiu-Shan & $\begin{array}{l}\text { Local Chinese orchestra, } \\
\text { Religious ceremony, Festival parties }\end{array}$ & Community office & $\begin{array}{l}\text { Membership fee, } \\
\text { Government funding }\end{array}$ \\
\hline Yong-Xin & $\begin{array}{l}\text { Elderly care, Computer and English } \\
\text { conversation classes, Festival parties, } \\
\text { Flea market, Community cleaning day }\end{array}$ & Community office & Membership fee \\
\hline Zhong-He & $\begin{array}{l}\text { Elderly care, Community cleaning-up } \\
\text { day, Community gardening day }\end{array}$ & Community office & Membership fee \\
\hline
\end{tabular}


Table 4. Cont.

\begin{tabular}{|c|c|c|c|}
\hline Characters & $\begin{array}{l}\text { Empowerment programs held by } \\
\text { community association } \\
\text { (Information obtained through } \\
\text { face-to-face interviewing } \\
\text { community associations) }\end{array}$ & $\begin{array}{l}\text { Most place chosen for } \\
\text { group gathering held by } \\
\text { community association }\end{array}$ & $\begin{array}{l}\text { Financial resource for } \\
\text { running community } \\
\text { association }\end{array}$ \\
\hline Urbanized Area & \multicolumn{3}{|c|}{ Mainly community office } \\
\hline Qi-Yan & $\begin{array}{l}\text { Ecotourism, Elderly care, Healthcare, } \\
\text { Old tree and wildlife protection works }\end{array}$ & Community office & $\begin{array}{l}\text { Membership fee, } \\
\text { Government funding }\end{array}$ \\
\hline Guan-Du & $\begin{array}{l}\text { Festival parties, Computer class, } \\
\text { Barbecue party, Religious ceremony }\end{array}$ & Riverfront & $\begin{array}{l}\text { Membership fee, } \\
\text { Government, Donation }\end{array}$ \\
\hline Zhen-Hua & Elderly care, Waste recycle, & Community office, Park & $\begin{array}{l}\text { Membership fee, } \\
\text { Government, Donation }\end{array}$ \\
\hline Li-Xian & $\begin{array}{l}\text { Flea market, Mountain hiking, Festival } \\
\text { parties, Drawing competition }\end{array}$ & Community office & $\begin{array}{l}\text { Membership fee, } \\
\text { Government, Donation }\end{array}$ \\
\hline Li-Nong & $\begin{array}{l}\text { Health care, Parenting class, } \\
\text { Childcare, Mountain hiking }\end{array}$ & Community office & $\begin{array}{l}\text { Membership fee, } \\
\text { Government, Donation }\end{array}$ \\
\hline Rong-Guang & $\begin{array}{l}\text { Elderly care, Singing class, Art } \\
\text { exhibition, Community gardening day }\end{array}$ & $\begin{array}{l}\text { Community office, } \\
\text { Community office }\end{array}$ & $\begin{array}{l}\text { Membership fee, } \\
\text { Government funding }\end{array}$ \\
\hline Fu-Xing & $\begin{array}{l}\text { Elderly care, Singing class, Festival } \\
\text { parties, Community cleaning-up day }\end{array}$ & $\begin{array}{l}\text { Community office } \\
\text { Community office }\end{array}$ & Membership fee \\
\hline Da-Tong & $\begin{array}{l}\text { Elderly care, Waste recycle, Festival } \\
\text { parties, Healthcare }\end{array}$ & $\begin{array}{l}\text { Community office, Public } \\
\text { green }\end{array}$ & $\begin{array}{l}\text { Membership fee, } \\
\text { Government funding }\end{array}$ \\
\hline Rong-Hua & $\begin{array}{l}\text { Community publication, Festival } \\
\text { parties, Community cleaning-up day, } \\
\text { Outdoor travel }\end{array}$ & $\begin{array}{l}\text { Private house, Community } \\
\text { office }\end{array}$ & $\begin{array}{l}\text { Membership fee, } \\
\text { Government funding, } \\
\text { Donation }\end{array}$ \\
\hline Ji-Qing & $\begin{array}{l}\text { Community cleaning-up day, Festival } \\
\text { parties, Flea market }\end{array}$ & Community office & $\begin{array}{l}\text { Membership fee, } \\
\text { Govern- ment funding }\end{array}$ \\
\hline Zhong-Yang & $\begin{array}{l}\text { Singing and conversation classes, } \\
\text { Festival parties }\end{array}$ & Community office & Membership fee \\
\hline Dong-Hua & $\begin{array}{l}\text { Elderly care, Community cleaning-up } \\
\text { day, Community gardening day }\end{array}$ & Community office & $\begin{array}{l}\text { Membership fee, } \\
\text { Government funding }\end{array}$ \\
\hline Wen-Hua & $\begin{array}{l}\text { Singing and dancing classes, Festival } \\
\text { parties, Outdoor travel }\end{array}$ & $\begin{array}{l}\text { Public parks, Community } \\
\text { office }\end{array}$ & Membership fee \\
\hline
\end{tabular}

\section{Empirical Evidence}

To examine the notion of "the shorter the distance of inner neighborhood travels resulting from having grocery stores and community services within certain distances in a neighborhood, the more the opportunities for residents to meet daily, thereby an SOC is strengthened", mode choices need to be understood before comparing the effectiveness between neighborhood accessibility and community empowerment program. Two major findings are discussed below. 


\subsection{Mode Choice for Daily Activities}

According to questionnaire surveys of the 19 selected neighborhoods, Table 5 shows that residents of suburban neighborhoods drive cars and ride motorcycles more frequently for works, shopping, banking, traveling to post office and clinics, and attending events. On the other hand, residents of urbanized neighborhoods often use cars, motorcycles, and transits for commuting to works. To reach banks and post offices or take children to schools, they either ride motorcycles or walk. Regarding other daily activities such as shopping, doing recreation, attending events, seeing doctors at clinic, and going to the library, residents of urbanized neighborhoods tend to walk to the places, due to greater accessibility of having facilities near residential houses within walking distance. Clearly, exclusive work-related commuting trips, residents of urbanized neighborhoods are likely to walk more for their daily activities.

Table 5. Mode choice for different travel purposes in Beitou's 19 neighborhoods.

\begin{tabular}{|c|c|c|c|c|c|c|c|c|c|}
\hline \multirow[b]{2}{*}{$\begin{array}{l}\text { Neighborhood } \\
\text { and Mode } \\
\text { Choices }\end{array}$} & \multicolumn{9}{|c|}{ Mode of Choice by Travel Purposes in Percentage } \\
\hline & $\begin{array}{c}\text { For } \\
\text { Works }\end{array}$ & $\begin{array}{l}\text { For Daily } \\
\text { Shopping }\end{array}$ & $\begin{array}{c}\text { For } \\
\text { Leisure }\end{array}$ & $\begin{array}{c}\text { Taking } \\
\text { Children } \\
\text { to School }\end{array}$ & $\begin{array}{c}\text { To } \\
\text { Bank }\end{array}$ & $\begin{array}{c}\text { To } \\
\text { Post } \\
\text { Office } \\
\end{array}$ & $\begin{array}{c}\text { To } \\
\text { Library }\end{array}$ & $\begin{array}{c}\text { To } \\
\text { Clinics }\end{array}$ & $\begin{array}{c}\text { To } \\
\text { Events }\end{array}$ \\
\hline \multicolumn{10}{|l|}{ Urbanized Area } \\
\hline By cars & $20 \%$ & $6 \%$ & $8 \%$ & $18 \%$ & $2 \%$ & $4 \%$ & $3 \%$ & $11 \%$ & $3 \%$ \\
\hline By motorcycles & $33 \%$ & $26 \%$ & $16 \%$ & $36 \%$ & $39 \%$ & $23 \%$ & $23 \%$ & $28 \%$ & $9 \%$ \\
\hline By bikes & $9 \%$ & $14 \%$ & $6 \%$ & $2 \%$ & $9 \%$ & $9 \%$ & $10 \%$ & $7 \%$ & $13 \%$ \\
\hline By walking & $17 \%$ & $51 \%$ & $68 \%$ & $41 \%$ & $46 \%$ & $61 \%$ & $58 \%$ & $43 \%$ & $73 \%$ \\
\hline By transits & $21 \%$ & $3 \%$ & $3 \%$ & $3 \%$ & $4 \%$ & $4 \%$ & $6 \%$ & $12 \%$ & $1 \%$ \\
\hline \multicolumn{10}{|l|}{ Suburban Area } \\
\hline By cars & $42 \%$ & $45 \%$ & $14 \%$ & $13 \%$ & $36 \%$ & $35 \%$ & $10 \%$ & $47 \%$ & $36 \%$ \\
\hline By motorcycles & $30 \%$ & $27 \%$ & $17 \%$ & $29 \%$ & $32 \%$ & $36 \%$ & $39 \%$ & $30 \%$ & $33 \%$ \\
\hline By bikes & $0 \%$ & $0 \%$ & $8 \%$ & $0 \%$ & $3 \%$ & $3 \%$ & $0 \%$ & $0 \%$ & $0 \%$ \\
\hline By walking & $14 \%$ & $7 \%$ & $55 \%$ & $56 \%$ & $15 \%$ & $7 \%$ & $26 \%$ & $4 \%$ & $28 \%$ \\
\hline By transits & $14 \%$ & $21 \%$ & $5 \%$ & $2 \%$ & $14 \%$ & $18 \%$ & $26 \%$ & $19 \%$ & $3 \%$ \\
\hline
\end{tabular}

\subsection{Comparison of Shortening Inner Neighborhood Travels and Encouraging Community Activity} Participation for Promoting a Stronger Psychological Sense of Community

To determine statistically significant importance between inner neighborhood travel and three types of community activity participation with PSOC, Table 6 lists the results of the forward stepwise regression. Based on a 95 percent confidence level, it shows that "Median travel distance exclusive work related commute" is the strongest factor correlating with PSOC; "Ratio of buildings higher than 5 stories" is the second; "Education level under college" is the third; "Persons per household" is the fourth; "Ratio of households of married couples with children" is the fifth; "Median distance from home to leisure places" is the sixth; "Frequency of attending individual meetings regularly" is the seventh; and "Frequency of casual meetings" is the eighth in the model. There are 11 variables removed from the regression, and they are population density, ratio of housing type under 3 stories, ratio of housing type between 3-5 stores, average distance from the neighborhood center to the closet 
mass transit station, mean duration of residency, ratio of households having married couples without child, median annual household income, and frequency of meeting neighbors when attending group activities arranged by community associations.

Table 6. Results of forward stepwise regression analysis.

\begin{tabular}{|c|c|c|c|c|}
\hline \multirow{2}{*}{$\begin{array}{l}\text { Regression Summary for } \\
\text { Dependent Variable: Median } \\
\text { degree of PSOC } \\
\mathrm{N}=19\end{array}$} & \multicolumn{4}{|c|}{$\begin{array}{l}\text { Forward Stepwise Regression Summary } \\
\left(R=0.98163159, R^{2}=0.96360057, \text { Adjusted } R^{2}=0.93448103,\right. \\
F(8,10)=33.091, p<0.00000, \text { Standard Error of estimate: } 0.02425)\end{array}$} \\
\hline & Step + in/- out & B & $t$-value(12) & $p$-level \\
\hline Intercept & & 0.444536 & 4,41989 & 0.001294 \\
\hline $\begin{array}{l}\text { Median travel distance exclusive } \\
\text { commuting trip }\end{array}$ & 1 & -0.001991 & -5.29806 & 0.000263 \\
\hline $\begin{array}{l}\text { Ratio of housing type higher than } \\
5 \text { stories in the neighborhood }\end{array}$ & 2 & 0.172702 & 4.59373 & 0.000990 \\
\hline $\begin{array}{l}\text { Ratio of education level under } \\
\text { college in the neighborhood }\end{array}$ & 3 & 0.151835 & 3.81848 & 0.003382 \\
\hline $\begin{array}{l}\text { Mean persons per household in } \\
\text { the neighborhood in year } 2009\end{array}$ & 4 & -0.164942 & -5.04524 & 0.000503 \\
\hline $\begin{array}{l}\text { Ratio of households of married } \\
\text { couples with children in the } \\
\text { neighborhood }\end{array}$ & 5 & 0.106275 & 1.78473 & 0.104620 \\
\hline $\begin{array}{l}\text { Median distance from home to } \\
\text { leisure places }\end{array}$ & 6 & -0.031738 & -3.53253 & 0.005424 \\
\hline $\begin{array}{l}\text { Frequency of attending individual } \\
\text { meetings regularly }\end{array}$ & 7 & 0.070187 & 2.40045 & 0.037287 \\
\hline Frequency of casual meetings & 8 & 0.032446 & 1.93187 & 0.082180 \\
\hline
\end{tabular}

Generally, statistical examination yields that "shortening inner neighborhood travel distance thereby providing more opportunities of social interactions" is more effective than "joining more group activities held by community associations" in terms of enhancing a PSOC. Moreover, neighborhoods having more residents participating in both individual gatherings and casual meetings seem to facilitate a stronger PSOC than the neighborhoods having more residents attending in formal group activities held by community associations.

Other than the strategy of mixing convenient stores and facilities of daily services within walking or cycling distances near residential locations in the neighborhood, approaches related to physical planning for promoting shorter inner neighborhood travels and enhancing an SOC also include:

(1) Provide enough incentives to encourage old neighborhood renewal so that homeownership organizations of those renewal residential buildings (taller than five stories) are able to help residents building strong community attachment. Based on Taiwan's "Apartment and Condominium Management Ordinance", developers of new high-rises and apartments have to set up a public funding (certain percentages of construction cost) and transfer it to homeownership associations later for maintaining communities. Other than collecting maintenance fee, homeownership associations often hold festival parties and regular homeownership meetings together with maintaining community safety and taking care of their 
surrounding outdoor space. Moreover, many new high-rises reserve the ground level as public activity space where residents can meet and interact with their neighbors easily. Their SOC is therefore stronger.

(2) Rearrange the underused outdoor spaces along the major pedestrian corridors to small public places such as corner cafes, so that residents can meet each other casually and having extra chances of social interaction.

Other findings derived from social and demographic examination (part of the results of the forward stepwise regression) are as follows.

(1) A neighborhood having larger percentages of residents of education level under college seems to build better community cohesion. Since Beitou district was once zoned as either agricultural or industrial land usages together with development limitation, residents were less wealthy and often blue-collar workers. They worked either in the neighborhood or adjacent districts, and have similar spare time to meet with each other thereby the degree of SOC is enhanced.

(2) A neighborhood having less numbers of persons per household is likely to form a stronger SOC. Based on interviews, we are told that young couples have no choice but to ask neighbors for taking care of their children, when both of them are busy on works. Therefore, a neighborhood having more households of fewer members is likely to increase opportunities of asking helps thereby the degree of SOC is elevated.

(3) A neighborhood having a larger ratio of households of married couples with children seems to maintain stronger community cohesion, due to parents having more chances of meeting each other while taking their children to schools or participating in school activities. This finding has been discovered by several other researchers as well $[2,4]$.

\section{Conclusions and Discussion}

By assuming that residents are capable of working through the differences on community issues via self-government and building stronger cohesion when social capital is strong, Hibbard and Lurie [33] in the end found that higher level of resident involvements might not lead to greater community consensus and a stronger SOC, after their investigating the process of developing a comprehensive plan for Jackson/Teton County, Wyoming through interviewing citizens and officials. Moreover, Rosenblatt and others [12] examined a master planned community of Springfield Lakes near Brisbane, Australian, by face-to-face interviewing residents and other actors (business owners, service providers, local council staff, etc.). They found that residents appeared satisfied with their place and were happy to attend entertainment and events provided by the developers, thereby showing high levels of attachment to place and a so-called SOC, which was believed by Rosenblatt and others as a sense of "imagined" community. They concluded that a higher degree of reported SOC is likely irrelevant to actual social interaction.

Although the Springfield Lakes community has a large lake surrounded by boardwalks, walking trails and bush lands as its focus point for getting residents out of their homes and walking around the estate, its physical design fails to place these facilities to the appropriate locations thereby resulting in inactive social interaction. Since 1994, Taiwan's Council for Affairs has promoted the citizen 
participation movement and many community associations believe that their SOC have been elevated [34]. However, this research did not find strong evidence supporting the notion of "neighborhoods having more residents participating in community events are likely to facilitate a stronger SOC", even though our survey samples were mainly based on residents being members of their community associations.

On the other hand, after examining Beitou's current community empowerment programs and neighborhood accessibility, this study supports that NU development is likely to foster a stronger SOC. The approach of shortening inner neighborhood travel distance through placing grocery stores and community services within certain distances close to home locations seems to create more opportunities enabling residents to meet each other either formally or informally thereby forming a stronger SOC, although Talen [1] doubts that creating a setting where residents come into close proximity to each other may not guaranty social interaction extensively.

Based on the consideration of a neighborhood is part of the planning unit of a town and instead of defining sustainability as "an ability or capacity of taking what we need to live now without compromising the potential for people in the future to meet their needs" [35], this research follows the concepts of Leadership in Energy and Environmental Design for Neighborhood Development (LEED-ND). The intent of sustainable neighborhood development aims at integrating the principles of smart growth, urbanism and green building into a national country system for neighborhood design [35], and provision of pedestrian-friendly environment has become a critical approach for decreasing automobile uses and strengthening an SOC [36,37].

In LEED-ND, it includes indicators of smart location, walkable streets, compact development, and connected and open community for minimum levels of energy consumption together with community outreach and involvement indicator for enhancing a stronger SOC. Xu and others [38] believe that a higher degree of SOC is associated with community empowerment, after their examining the status of SOC and neighboring behavior together with social capital in the People's Republic of China for understanding their ability of predicting local political participation. To make a neighborhood have greater consensus and a stronger SOC, both strategies of placing neighborhood stores and services close to home and along with main arterials together with arranging various community empowerment programs have to be adopted simultaneously.

In Taipei's Beitou District, residents of urbanized neighborhoods generally have greater accessibility reaching various facilities within shorter distances by walking or cycling due to $14 \%$ of residential houses mixed with neighborhood stores and services on their ground floor [38]. By saving time in driving cars or riding motorcycles, they interact with neighbors when they walk to grocery stores, parks, stations, libraries banks, or clinics. The urbanized neighborhoods therefore show stronger community cohesion than the suburban neighborhoods ( $9 \%$ of mixed uses) where have inadequate daily services and stores within the area. The approach of mixed land-uses has played an important role facilitating pedestrian friendly environment. However, the potential of applying mixed uses approach to strengthen an SOC for suburban neighborhoods may not be appropriated due to a lack of enough population density supporting neighborhood businesses. Instead, the improvement of current community empowerment programs applied in suburban neighborhoods is likely to be more effective.

Finally, $\mathrm{Xu}$ and others [39] argue that the content of SOC in China is likely to be different from Western theories, since Chinese communities are built traditionally based on patrilineal kinship network within a geographic area where extended families live proximately. The family members take 
care of each other when there is a need. They also believe that interpersonal relations such as knowing neighbors, mutual support and helping each other could be influenced by local participations [39]. Since contact with neighbors, social support, similarity, community involvement and attachment are components of measuring PSOC, the family related geographic area issue should be addressed in a further PSOC discussion. Moreover, this study initially assumed there is a relationship linking community identity with SOC. However, the study in the end finds that unique community identity may not lead to a stronger PSOC, and an advanced study therefore is needed.

\section{Conflicts of Interest}

The author declares no conflict of interest.

\section{References}

1. Talen, E. Sense of Community and Neighborhood Form: An Assessment of the Social Doctrine of New Urbanism. Urban Stud. 1999, 36, 1361-1379.

2. Nasar, J.L.; Julian, D.A. The Psychological Sense of community in the Neighborhood. J. Am. Plan. Assoc. 1995, 61, 178-184.

3. Garde, A.M. New Urbanism as Sustainable Growth? A Supply Side Story and Its Implications for Public Policy. J. Plan. Educ. Res. 2004, 24, 154-170.

4. Lund, H. Pedestrian Environments and Sense of Community. J. Plan. Educ. Res. 2002, 21, 301-312.

5. Kim, J.; Kaplan, R. Physical and Psychological Factors in Sense of Community: New Urbanist Kenlands and Nearby Orchard Village. Environ. Behav. 2004, 36, 313-340.

6. Tseng, S.C. Community Building in Taiwan; Walkers Cultural Enterprise Ltd.: New Taipei City, Taiwan, 2009. (In Chinese)

7. Wu, K.L. Developing an Evaluation Framework for Community Empowerment from the Viewpoint of Sustainable Communities: A Study on the Experiences of Tainan City and Tainan County. J. Housing Stud. 2007, 16, 21-55. (In Chinese)

8. Sarason, S.B. The Psychological Sense of Community: Prospects for a Community Psychology; Jossey-Bass: San Francisco, CA, USA, 1974.

9. McMillan, D.W.; Chavis, D.M. Sense of Community: A Definition and Theory. J. Community Psychol. 1986, 14, 6-23.

10. Perkins, D.D.; Long, D.A. Neighborhood Sense of Community and Social Capital: A Multi-level Analysis. In Psychological Sense of Community: Research, Applications, and Implications; Fisher, A.T., Sonn, C.C., Bishop, B.J., Eds.; Plenum: New York, NY, USA, 2002; pp. 291-318.

11. Putnam, R.D. Bowling Alone: American's Declining Social Capital. J. Democr. 1995, 6, 65-78.

12. Rosenblatt, T.; Cheshire, L.; Lawrence, G. Social Interaction and Sense of Community in a Master Planned Community. Hous. Theory Soc. 2009, 26, 122-142.

13. Relph, E. Place and Placelessness; Pion Books: London, UK, 1976.

14. Gospodini, A. Urban Morphology and Place Identity in European Cities: Built Heritage and Innovative Design. J. Urban Des. 2004, 9, 225-248.

15. Hummon, D.M. Commonplaces: Community Ideology and Identity in American Culture; State University of New York Press: Albany, NY, USA, 1990. 
16. Kim, J. Perceiving and Valuing Sense of Community in a New Urbanist Development: A Case Study of Kentlands. J. Urban Des. 2007, 12, 203-230.

17. Keen, M.; Mahanty, S.; Sauvage, J. Sustainability Assessment and Local Government: Achieving Innovation through Practitioner Network. Local Envir. 2006, 11, 201-216.

18. Punter, J. Participation in the Design of Urban Space. Landscape Des. 1991, 200, $24-27$.

19. Montgomery, J. Making a City: Urbanity, Vitality and Urban Design. J. Urban Des. 1998, 3, 93-116.

20. Gotham, K.F. Political Opportunity, Community Identity, and the Emergence of a Local Anti-Expressway Movement. Soc. Probl. 1999, 46, 332-354.

21. Lee, Y.J. Community Empowerment vis-à-vis Globalization: Case of Taiwan. J. State and Soc. 2009, 7, 1-27. (In Chinese)

22. Jabareen, Y.R. Sustainable Urban Forms: Their Typologies, Models, and Concepts. J. Plan. Educ. Res. 2006, 26, 38-52.

23. Carmona, M.; Tiesdell, S.; Heath, T.; Oc, T. Public Places Urban Spaces: The Dimensions of Urban Design; Architectural Press: Oxford, UK, 2010.

24. Handy, S.; Clifton, K.J. Evaluating Neighborhood Accessibility: Possibilities and Practicalities. J. Transport. Stat. 2001, 4, 67-78.

25. Bromley, R.D.F.; Tallon, A.R.; Thomas, C.J. City Centre Regeneration through Residential Development: Contributing to Sustainability. Urban Stud. 2005, 42, 2407-2429.

26. Tsai, T.A. A Study of Integrating the Principles of New Urbanism with Urban Development Indicators for Achieving Community Sustainability-Case of the Communities in Beitou District, Taipei, Taiwan; Research Project ID: NSC96-2415-H-034-009-SS2; National Science Council: Taipei, Taiwan, 2009. (In Chinese)

27. Glynn, T.J. Psychological Sense of Community: Measurement and Application. Hum. Relat. 1981, $32,789-818$.

28. Filipovič Hrast, M.; Dolničar, V. Sense of Community and the Importance of Values: Comparison of Two Neighborhoods in Slovenia. J. Urban Aff. 2011, 34, 317-336.

29. Herson, L.J.R.; Bolland, J.M. The Urban Web: Politics, Policy, and Theory; Nelson-Hall Publishers: Chicago, IL, USA, 1991.

30. Barrett, B.; Usui, M. Local Agenda 21 in Japan: Transforming Local Environmental Governance. Local Envir. 2002, 7, 49-67.

31. Chang, H.C. A Study on Basic Agricultural Extension Organizations Involving Taiwan's Rural Community Empowerment Program. Community Dev. J. 2007, 120, 312-329. (In Chinese)

32. Nishisato, S. Dual Scaling. In The Sage Handbook of Quantitative Methodology for the Social Sciences; Kaplan, D., Ed.; SAGE Publications, Inc.: Thousand Oaks, CA, USA, 2004; pp. 3-24.

33. Hibbard, M.; Lurie, S. Saving Land but Losing Ground: Challenges to Community Planning in the Era of Participation. J. Plan. Educ. Res. 2000, 20, 187-195.

34. Wang, A. Reclaiming a Sense of Community. Taiwan Review, 1 April 2008. Available online: http://taiwanreview.nat.gov.tw/fp.asp?xItem=30741\&CtNode=119 (accessed on 16 March 2012).

35. Davidson, K.M.; Venning, J. Sustainability Decision-making Frameworks and the Application of Systems Thinking: An Urban Context. Local Envir. 2011, 16, 213-228.

36. Mapes, J.; Wolch, J. "Living Green": The Promise and Pitfalls of New Sustainable Communities. J. Urban Des. 2011, 16, 105-126. 
37. Rohe, W.H. From Local to Global: One Hundred Years of Neighborhood Planning. J. Am. Plan. Assoc. 2009, 75, 209-230.

38. Tsai, T.A. What Businesses and Services Promote Shorter Inner Neighborhood Travels under Mixed Land Uses Strategy? J. Habitat Eng. Des. 2013, 5, 49-64.

39. Xu, Q.; Perkins, D.D.; Chow, J.C.C. Sense of Community, Neighboring, and Social Capital as Predictors of Local Political Participation in China. Am. J. of Community Psychol. 2010, 45, 259-271.

(C) 2014 by the author; licensee MDPI, Basel, Switzerland. This article is an open access article distributed under the terms and conditions of the Creative Commons Attribution license (http://creativecommons.org/licenses/by/3.0/). 